\title{
HOMENAGENS
}

\section{MORTE DE UM CORAJOSO}

\author{
Bruno Tackels* \\ bruno.tackels@wanados.fr
}

Na noite de 28 a 29 de janeiro, ofilósofo Philippe Lacoue-Labarthe parou de respirar. Com seu desaparecimento, perdemos um de nossos filósofos mais essenciais. Mesmo que ele tenha sempre escolhido o partido do retraimento, sua reflexão sobre a arte e sobre a politica, notadamente aquela de todos os extremismos, são uma referência decisiva para apreender nossa época desorientada.

O filósofo Philippe Lacoue-Labarthe faleceu no último fim de semana, após uma longa briga com a morte. Uma luta que se parece com o que foi sua vida, sempre exposta às mais altas exigências do pensamento. Uma visão elevada a que se obrigou, durante toda sua vida, com uma coragem que impõe o respeito. Sim, era corajosamente que o pensamento de Lacoue-Labarthe se construía, de ensaios a cursos, de conferências a análises: um pensamento sem concessão. Que se confrontou, durante mais de quarenta anos, com a questão mais densa que foi posta aos filósofos do fim do século XX: como compreender que Martin Heidegger, o maior filósofo desse século, se tenha comprometido a tal ponto (isto é, indo tão longe, e durante tanto tempo) com o nacional-socialismo? E, a partir disso, o que se deve concluir sobre o que é a própria filosofia? E o que pensar da nossa maneira, justamente, de sempre querer compreender, moldar, decidir para o mundo?

Era preciso muita coragem para afrontar verdadeiramente essa questão. Durante décadas, Lacoue-Labarthe não parou de fazê-lo. Ele viera e analisara

* Professor do Departamento de Artes Cênicas da Universidade de Rennes 2, Haute Bretagne, França.

KRITERION, Belo Horizonte, nº 115, Jun/2007, p. 277-278. 
perfeitamente que Heidegger tinha se entregado à política nazista apropriando-se de uma certa idéia de arte e, particularmente, da poesia. Foi em nome de uma certa idéia da poesia que o povo pôde construir-se como uma entidade odienta, destruidora e aniquiladora de qualquer outro.

Portanto, foi buscando sem cessar uma outra poesia, como experiência, que Lacoue-Labarthe pretendeu responder a Heidegger. Para conjurar suas sereias e tentar pensar de maneira diferente. No entanto, e aí está sua coragem, nunca se deixou enganar por aqueles que viam um antídoto, um contrapeso, no comunismo real. De toda figura sedutora e identitária, ele sempre desconfiou, com uma intransigência terrível. Até intratável. Porque o homem pós-metafísico finda, expõe-se, como um ser estritamente finito, a nada mais senão a esta morte que lhe vem - um ser que, após todas as formas de heroísmo, somente se pode pensar nessa relação inegociável com a morte. Que nada pode salvar. Mas que pode ainda fazer frases, e cenas para suas frases - uma experiência da poesia que expõe ao essencial, e que não fica incólume. Lacoue engajou-se completamente nessa busca, através da escrita filosófica, mas também literária, ou por suas incursões no espaço do teatro. Portanto, ele não se poupou, nem naquela busca de um pensamento radical, nem na sua vida - forçosa e integralmente mantidas juntas. Foi-lhe necessária muita coragem. E ele a teve. Ele a legou a todos os seus leitores, os primeiros leitores, seus estudantes, e depois, a todos que vão seguir. Obrigado, Philippe.

Paris

Fevereiro de 2007.

(Tradução de Virginia Figueiredo) 